\title{
Role of endogenous opioid peptides in the acute adaptation to hypoxia
}

\author{
Kimberly P. Mayfield ${ }^{\mathrm{a}}$ and Louis G. D'Alecy ${ }^{\mathrm{a}, \mathrm{b}}$ \\ The Univ'ersity of Michigan Medical School, Departments of a Phystology and 'Surgery, Ann Arbor, MI 48109-0622 (USA)
}

(Accepted 21 January 1992)

Key words Brain damage, Hypoxia; Conditıoning; Naloxone, Morphine, Endogenous opıo1d peptıde, $\mu$ Opıo1d receptor

\begin{abstract}
A non-lethal, hypoxic conditioning stımulus has been shown by Rising and D'Alecy to increase hypoxic survival time in mice To determine if endogenous opioids alter the hypoxic conditıoning-induced increase in hypoxic survival time, we administered naloxone (0 1, 10 $\mathrm{mg} / \mathrm{kg}$ ı.p.) or salıne $(0.3 \mathrm{ml} 1 \mathrm{p}) 5 \mathrm{~min}$ prior to conditıonıng. Sixty percent of the mice received the hypoxic conditionıng stımulus consistıng of three sequential hypoxic exposures ( $4.5 \%$ oxygen balance nitrogen for $1.5,2$ and $2.5 \mathrm{~min}$ ) separated by 5 mın of room air The remainıng mice did not receive hypoxic conditioning but instead remained in room air for this time All mice were tested for hypoxic survival by first exposing them to $20 \mathrm{~s}$ of $8.5 \%$ oxygen balance nitrogen followed by exposure to $4.5 \%$ oxygen balance nitrogen The hypoxic survival tıme was recorded as the time from the onset of the $4.5 \%$ oxygen to the cessation of spontaneous ventilation Naloxone (1 mg/kg) completely blocked the adaptation to hypoxia induced by hypoxic conditioning $(P=0003)$ Morphine $(1,5,10$ and $20 \mathrm{mg} / \mathrm{kg})$ had no effect on hypoxic adaptation, however, $50 \mathrm{mg} / \mathrm{kg}$ morphine decreased the adaptation induced by conditioning $(P<0.0001)$ possibly due to high dose toxicity These data suggest that endogenous opioids are involved in the protective adaptation to hypoxia induced by prior exposure to non-lethal hypoxia
\end{abstract}

\section{INTRODUCTION}

Conditioning to stressors such as hypoxia and ischemia has been accomplished in many cases by previous less severe exposure to certain stressors. For example, prior exposure to hypoxia increases hypoxic tolerance in an ensuing hypoxic challenge $e^{21,26}$; brief ischemic bouts protect from subsequent ischemic damage in hippocampal neurons ${ }^{10}$; and hyperthermia has been shown to protect against ensuing ischemic exposures in both the rat ${ }^{4}$ and gerbil ${ }^{14}$. The mechanisms by which an animal adapts acutely to hypoxic or ischemic stress have potential to be used in the development of clinical interventions to improve the outcome of medical and surgical procedures or trauma. Hypoxia is related to significant morbidity and mortality in a number of clinical settings including head injury apnea ${ }^{15.22}$ and altitude sickness ${ }^{24}$.

Previous work in our laboratory has shown that mice exposed to three non-lethal hypoxic periods will have a significantly greater tolerance when subsequently exposed to lethal hypoxia. ${ }^{21}$ This hypoxic conditioning stımulus presumably alters one or more systems in the mice to effect this improved outcome. Many candidates have been suggested as potential mediators of the conditioning effect in this and other models. These candi- dates generally involve components of the stress response such as the appearance of $\beta$-hydroxybutyrate in the blood $^{21}$ and the synthesis of heat shock proteins ${ }^{10}$. A central mechanism of adaptation is proposed because brain electrical activity is reduced in response to hypoxia and ultimately ceases prior to respiratory and cardiovascular collapse ${ }^{16}$. A pathway can therefore be hypothesized in which hypoxic stress is the stımulus for an integrated central nervous system response that produces systemic changes to improve hypoxic tolerance.

A review by Akil et al. supports the theory that a major function of the opioid systems is to orchestrate the variety of physiological changes known as the stress response The localization of opioids and their receptors in important regulatory nuclei in the autonomic nervous system implicate a central role of opioids in controlling the stress response ${ }^{1}$. We hypothesized that the central action of endogenous opioid peptides is a necessary step in the acute adaptation to hypoxia that occurs during hypoxic conditioning. The studies presented here answer the more specific question: will the general opioid receptor antagonist, naloxone ${ }^{7}$, diminish the hypoxic cond1tioning effect? If opionds are involved in the acute adaptation to hypoxia, then naloxone would be expected to attenuate the conditioning effect. In addition, this 
study determined whether hypoxic conditioning can be augmented by using the opioid agonist, morphine.

\section{MATERIALS AND METHODS}

Adult male albino mice (Mus musculus, Charles Ruver, CD-1) weighing 15-32 $\mathrm{g}$ were housed in a 12:12 light-dark cycle and fed rat and mouse chow (Purina) with water avallable ad lib

Naloxone hydrochlonde (Lyphomed, $04 \mathrm{mg} / \mathrm{ml}$ ) and morphine sulfate (Elkins-Sinn, Inc , $15 \mathrm{mg} / \mathrm{ml}$ ) were diluted in sterile $0.9 \%$ saline solution to allow 1.p. injections of less than $0.4 \mathrm{ml}$.

Each mouse received an 1.p. injection of either naloxone $(0.1,1$ $\mathrm{mg} / \mathrm{kg})$ at minus $5 \mathrm{~min}$, morphine $(1,5,10,20$ or $50 \mathrm{mg} / \mathrm{kg})$ at $\mathrm{ml}$ nus $30 \mathrm{~min}$, or salıne $(03 \mathrm{ml})$ at corresponding times before conditıoning. Mice were weighed and individually dosed according to body weight. Mice injected 30 min prior to conditioning were kept in temporary housing in which a lamp was used to warm part of the cage and therefore provide a temperature gradient which the mice could use to minımize any thermal stress. The mice injected 5 min pror to conditioning were immediately placed in the cond1tioning chambers. The conditioning ${ }^{21}$ and hypoxia ${ }^{23}{ }^{25}$ models have been previously described and used by our laboratory ${ }^{6.11-13} 20.21$ During the conditioning, mice were put in either of two $500 \mathrm{ml}$ airtight flow-through chambers. The temperature of each chamber was continuously recorded (Honeywell recorder) using a copper constantan thermocouple. A proportional temperature controller was used to maintain the temperature of the conditioning chambers near $30.9^{\circ} \mathrm{C}$, the thermoneutral zone of the mouse ${ }^{8}$. This was done to reduce any effects thermal stress could have durng the conditioning. The sham and hypoxic conditioning chambers were flushed with room air (20\% oxygen) at $1.3 \mathrm{l} / \mathrm{min}$ or $4.5 \%$ oxygen balance nitrogen at $1.3 \mathrm{l} / \mathrm{min}$. Three mice ( $\mathrm{HC}$, hypoxic conditioning) in the experimental chamber received three sequential exposures to the $45 \%$ oxygen for 15,2 and $25 \mathrm{~min}$ separated by $5 \mathrm{~min}$ of room air; two mice (SC, sham conditioning) in the sham chamber received room air for this entire duration After the mice were removed from the chambers and during the final $5 \mathrm{~min}$ interval in room air, a thermocouple was inserted $2 \mathrm{~cm}$ into the rectum of each mouse, and the mice were placed in five parallel and individual artight, flow-through, $110 \mathrm{ml}$ chambers to measure the hypoxic survival time (HST). The five chambers were initially flushed for $20 \mathrm{~s}$ with $8.5 \%$ oxygen balance nitrogen at $17 \mathrm{l} / \mathrm{min}$ and then flushed with $45 \%$ oxygen balance nitrogen at $1.3 \mathrm{l} / \mathrm{min}$; the percent oxygen actually flowing through the chambers was measured with an oxygen analyzer (Beckman OM-14). HST was determined as previously described ${ }^{611-1320212325}$ as the time from the onset of the $45 \%$ oxygen to the cessation of spontaneous ventilation Mice stıll alıve after $900 \mathrm{~s}(15 \mathrm{~min})$ were considered survivors and the test was concluded.

Statistical analyses of rectal temperature were calculated using ANOVA and an unpaired, two-tailed, Student's two-sample $t$-test with Bonferroni's correction for multiple compansons. HST was analyzed using survival curves generated by the computer program BMDP P1L ${ }^{2}$. This program applied Breslow's version of the generalızed Wilcoxon test (analogous to the Kruskal-Wallıs non parametric rankıng test) to test for similarity between the generated curves $^{3}$. A comparison was made among the survival curves of similarly treated mice (either $\mathrm{HC}$ or $\mathrm{SC}$ ) receiving the same drug and the corresponding saline control. For example, the HC salıne $5 \mathrm{~min}, \mathrm{HC}$ naloxone $01 \mathrm{mg} / \mathrm{kg}$, and the $\mathrm{HC}$ naloxone $1 \mathrm{mg} / \mathrm{kg}$ curves were compared for detection of a change caused by the drug. If the group comparison showed a significant difference, then comparisons were made between curves for each drug dose and the saline curve in that group to detect which dose was effective in causing a difference. Bonferroni's correction for multiple comparisons was also applied to the survival curve analysis to correct for multiple comparisons to the salıne controls. Mice that died dunng the course of the hypoxic conditioning were not included in statistical analyses of HST. Hypoxic conditioning mortality rates were ana-

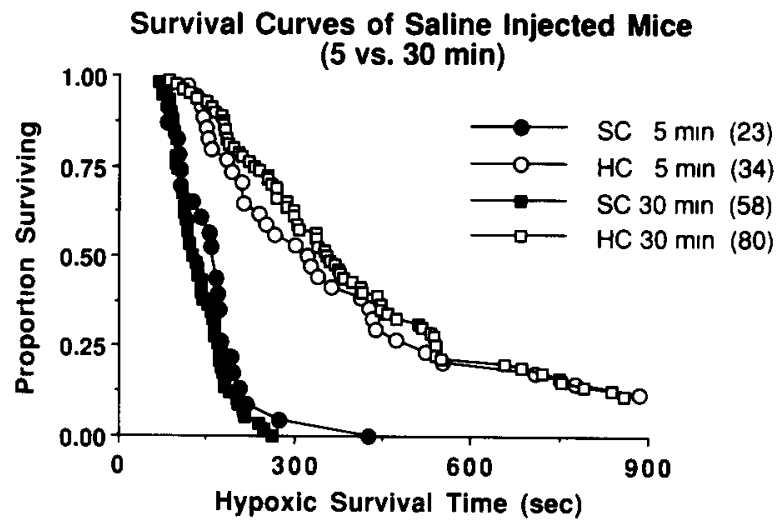

Fig 1. Survival curves for $\mathrm{HC}$ and SC groups injected with salıne $30 \mathrm{~min}$ and $5 \mathrm{~min}$ prior to pretreatment. Time of injection had no effect on the survival curves $\mathrm{HC}$ mice had significantly longer survival times than SC mice $(P<0.0001$, Breslow). Survival time axis is $900 \mathrm{~s}$ for this and all subsequent figures to facilitate comparison Numbers in parentheses indicate sample sıze HC, hypoxıc conditioning; SC, sham conditionıng

lyzed using Fisher's exact test.

\section{RESULTS}

Both naloxone and morphine altered the hypoxic conditioning-induced increase in HST. Hypoxic conditioning-induced changes in rectal temperature were also modified by these drugs.

\section{TABLE I}

\section{Rectal temperature $\left(T_{r}\right)$ at start of hypoxic survival test}

Rectal temperatures measured immediately prior to the onset of the hypoxic survival test. $\mathrm{HC}$ mice have significantly lower temperatures than SC mice for all treatments $(P=0.0001$, Student's $t$-test). Mice receiving $1 \mathrm{mg} / \mathrm{kg}$ naloxone had higher $T_{\mathrm{r}}$ compared to $T_{\mathrm{r}}$ of $\mathrm{HC}$ saline mice injected at $5 \mathrm{~min} .10 \mathrm{mg} / \mathrm{kg}$ morphıne increased $T_{\mathrm{r}}$ of SC mice compared to SC saline mice injected at 30 min. HC, hypoxıc conditıoning; SC, sham conditioning.

\begin{tabular}{lllll}
\hline & \multicolumn{4}{l}{$T_{r}$ Mean $\pm S$ E.M. $\left({ }^{\circ} \mathrm{C}\right)$} \\
\cline { 2 - 4 } & $S C$ & $n$ & $H C$ & $n$ \\
\hline $\begin{array}{l}\text { Drug/Dose } \\
\text { Saline (5 min) }\end{array}$ & $37.6 \pm 0.2$ & 23 & $356 \pm 0.1$ & 34 \\
Naloxone & & & & \\
$0.1 \mathrm{mg} / \mathrm{kg}$ & $38.0 \pm 01$ & 9 & $36.1 \pm 0.1$ & 15 \\
$1.0 \mathrm{mg} / \mathrm{kg}$ & $38.1 \pm 0.1$ & 22 & $36.8 \pm 0.2^{*}$ & 19 \\
Saline (30 min) & $37.9 \pm 0.1$ & 55 & $35.9 \pm 01$ & 77 \\
Morphine & & & & \\
$1 \mathrm{mg} / \mathrm{kg}$ & $378 \pm 02$ & 18 & $35.9 \pm 0.2$ & 24 \\
$5 \mathrm{mg} / \mathrm{kg}$ & $37.9 \pm 0.4$ & 18 & $36.0 \pm 0.2$ & 28 \\
$10 \mathrm{mg} / \mathrm{kg}$ & $385 \pm 0.1 * *$ & 24 & $36.1 \pm 0.1$ & 29 \\
$20 \mathrm{mg} / \mathrm{kg}$ & $37.6 \pm 0.1$ & 26 & $35.8 \pm 0.1$ & 43 \\
$50 \mathrm{mg} / \mathrm{kg}$ & $37.9 \pm 0.3$ & 14 & $36.3 \pm 0.2$ & 17 \\
\hline
\end{tabular}

${ }^{*} P=0.0002$ compared to $\mathrm{HC}$ sal $5 \min T_{\mathrm{r}}{ }^{* *} P=0.007 \mathrm{com} \cdot$ pared to $\mathrm{SC}$ sal $30 \mathrm{~min} T_{\mathrm{r}}$. 


\section{Hypoxic conditioning (saltne)}

Hypoxic conditioning increased the HST compared to mice receiving the sham conditioning (Fig. 1). This increase was seen in mice injected with saline at either 5 or $30 \mathrm{~min}$ prior to conditioning ( $P<0.0001$, Breslow). The mean HST of SC mice was $139 \pm 6 \mathrm{~s}(30 \mathrm{~min})$ and $164 \pm 16 \mathrm{~s}(5 \mathrm{~min})$ compared to the mean HST of HC mice which was $426 \pm 28 \mathrm{~s}(30 \mathrm{~min})$ and $401 \pm 45 \mathrm{~s}(5$ $\mathrm{min})$. A significant decrease in rectal temperature was observed in the $\mathrm{HC}$ mice in both 30 and $5 \mathrm{~min}$ injection groups $(P=0.0001$, Student's $t$-test, see Table I). Time of injection ( 30 or $5 \mathrm{~min}$ ) did not cause a significant difference in either HST or rectal temperature.

\section{Naloxone}

Naloxone at $1 \mathrm{mg} / \mathrm{kg}$ significantly reduced the HST in SC mice $(P=0.003$, Breslow, Fig. 2 top panel). This same dose of naloxone blocked the hypoxic conditioning-induced increase in HST $(P=0.0003$, Breslow, Fig. 2 bottom panel). The block of the $\mathrm{HC}$ effect was complete to the extent that no significant difference was detected between the survival curves of $\mathrm{HC}$ mice receiving $1 \mathrm{mg} / \mathrm{kg}$ naloxone and $\mathrm{SC}$ mice receiving saline $(P=$ 0.4362, Breslow, Fig. 3). In addition, there was an increase in the mortality rate during the hypoxic condi-
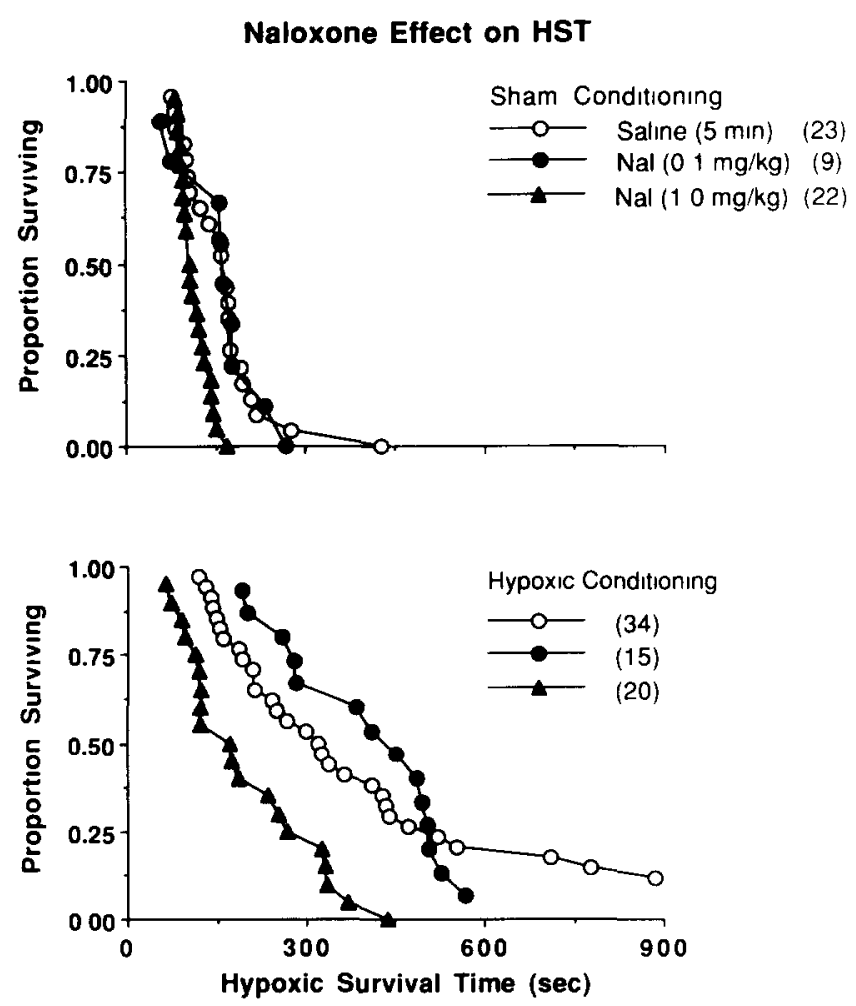

Fig. 2. Survival curves of SC mice (top) and HC mice (bottom) receiving saline, 0.1 or $10 \mathrm{mg} / \mathrm{kg}$ naloxone $1 \mathrm{mg} / \mathrm{kg}$ naloxone decreases survival time compared to saline in both $\mathrm{SC}$ and $\mathrm{HC}$ mice $(P \leq 0.003$, Breslow). Numbers in parentheses indicate sample stze

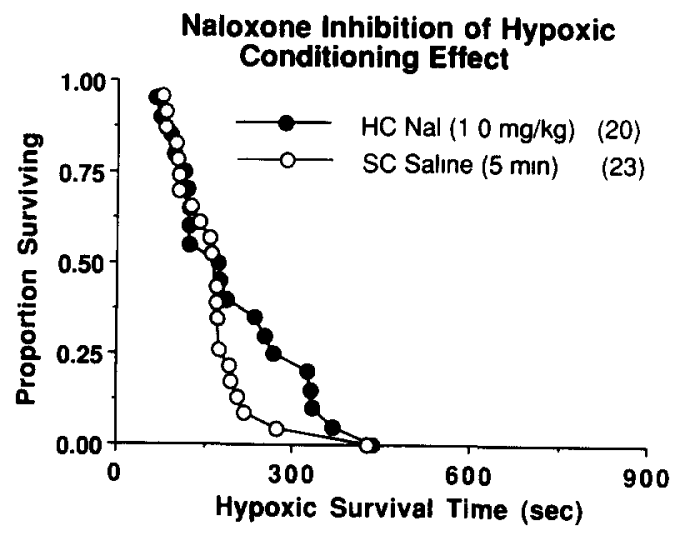

Fig. 3. Survival curves of $\mathrm{HC}$ mice given $1 \mathrm{mg} / \mathrm{kg}$ naloxone (repeated from bottom of Fig. 2) and SC mice given salıne (from top of Fig 2) No significant difference was detected between the two curves by the Breslow test indicating a complete block of the hypoxic conditioning effect by naloxone. Numbers in parentheses indicate sample sıze. $\mathrm{HC}$, hypoxıc conditioning, SC, sham conditioning

tioning from $5.5 \%$ in the saline-treated $\mathrm{HC}$ mice to $37.5 \%$ in the $\mathrm{HC}$ mice receiving $1 \mathrm{mg} / \mathrm{kg}$ naloxone $(P=$ 0.002 , Fisher's exact, Table II). The decrease in rectal temperature that accompanies hypoxic conditioning was

\section{Morphine Effect on HST}
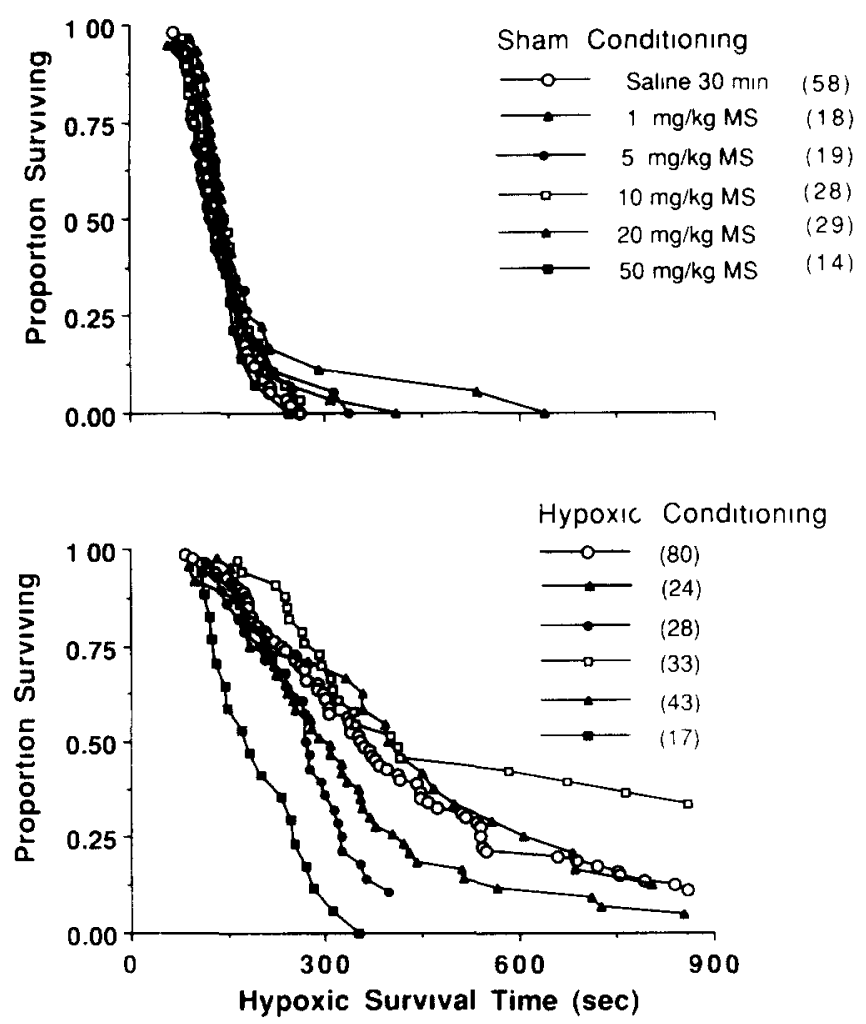

Fig. 4. Survival curves of $\mathrm{SC}$ mice (top) and $\mathrm{HC}$ mice (bottom) recelving etther salıne, $1,5,10,20$ or $50 \mathrm{mg} / \mathrm{kg}$ morphine (MS). 50 $\mathrm{mg} / \mathrm{kg}$ decreased the survival time in HC mice compared to salıne HC mice $(P<0.0001$, Breslow). Numbers in parentheses indicate sample size 


\section{TABLE II}

\section{Hypoxic conditioning mortality rate}

Percent mortality occurring during hypoxic conditioning is shown for each group $1 \mathrm{mg} / \mathrm{kg}$ naloxone has significantly increased mortality during hypoxıc conditioning $\left({ }^{*} P=0.002\right.$, Fisher's exact) $\mathrm{HC}$, hypoxic conditionıng, SC, sham conditıonıng.

\begin{tabular}{lcc}
\hline & $\begin{array}{l}\text { Percent } \\
\text { mortalty }\end{array}$ & $\begin{array}{l}\text { No deaths/ } \\
\text { No total HC mice }\end{array}$ \\
\hline $\begin{array}{l}\text { Drug/Dose } \\
\text { Saline }(5 \mathrm{~min})\end{array}$ & & \\
Naloxone & 5.5 & $2 / 36$ \\
$0.1 \mathrm{mg} / \mathrm{kg}$ & & \\
$1.0 \mathrm{mg} / \mathrm{kg}$ & 0 & $0 / 15$ \\
Salıne $(30 \mathrm{mın})$ & $37.5^{*}$ & $12 / 32$ \\
Morphine & 8.0 & $7 / 87$ \\
$1 \mathrm{mg} / \mathrm{kg}$ & & \\
$5 \mathrm{mg} / \mathrm{kg}$ & 7.6 & $2 / 26$ \\
$10 \mathrm{mg} / \mathrm{kg}$ & 9.6 & $3 / 31$ \\
$20 \mathrm{mg} / \mathrm{kg}$ & 15.3 & $6 / 39$ \\
$50 \mathrm{mg} / \mathrm{kg}$ & 2.2 & $1 / 44$ \\
\hline
\end{tabular}

also blunted ( $P=0.0002$, Student's $t$-test, see Table I). None of these effects were detected at $0.1 \mathrm{mg} / \mathrm{kg}$ naloxone.

\section{Morphine}

None of the five doses of morphine produced a detectable change in the survival curve for SC mice (Fig. 4 top panel). However, $50 \mathrm{mg} / \mathrm{kg}$ morphine blocked the hypoxic conditioning-induced increase in HST $(P<$ 0.0001, Breslow, Fig. 4 bottom panel). Rectal temperatures of SC mice given $10 \mathrm{mg} / \mathrm{kg}$ morphine were higher than SC mice given saline ( $P=0.007$, Student's $t$-test, Table I). No statistically significant changes were detected in either HST or temperature with the other doses of morphine, and no significant effect on mortality during hypoxic conditioning was detected.

\section{DISCUSSION}

The goal of these studies was to explore the hypothesis that the central action of endogenous opioid peptides is necessary in the acute adaptation to hypoxia that occurs during hypoxic conditioning. The confirmation that hypoxic conditioning increases HST supports earlier observations of this phenomena using this same model $^{21}$. Rising found that hypoxic conditioning increased HST from $108 \pm 4 \mathrm{~s}$ to $403 \pm 42 \mathrm{~s}^{21}$ comparing favorably with the current observation of an increase in HST from $139 \pm 6 s$ and $164 \pm 16 s$ to $426 \pm 28 s$ and $401 \pm$ $45 \mathrm{~s}$ (30 and 5 min saline injection times).

The new question this study approached was the dependence of this conditioning response on endogenous opioid peptides. We tested this hypothesis by administering naloxone, a narcotic antagonist ${ }^{7}$. The data indicates that $1 \mathrm{mg} / \mathrm{kg}$ naloxone was sufficient to block acute adaptation to hypoxia. Mice given this dose of naloxone failed to show the increase in hypoxic tolerance after hypoxic conditioning. Additionally, the increased hypoxic conditioning mortality rate in mice given this dose of naloxone indicates that the adaptation necessary to survive the hypoxic conditioning stimulus is blocked. Further, one would also suspect that some adaptation occurs during the actual hypoxic survival test, and the ability of $1 \mathrm{mg} / \mathrm{kg}$ naloxone to shorten the HST of SC mice indicates that even the minimal adaptation that occurs during the hypoxic survival test is blocked. The failure of adaptation to occur reflected by these three parameters (hypoxic conditioning-induced increase in HST, hypoxic conditioning mortality and HST) in the presence of $1 \mathrm{mg} / \mathrm{kg}$ naloxone suggests that acute adaptation is dependent on the binding of endogenous opioids to a naloxone blockable receptor(s) implicating that endogenous opioids are protective in this setting. Naloxone given at low doses as in this study is very specific for opioid receptors. Also, doses given in this study are far below the $\mathrm{LD}_{50}$ of $286 \mathrm{mg} / \mathrm{kg}$ s.c. ${ }^{19}$, making it unlikely that any of the effects are due to toxicity.

Blockade of the hypoxic conditioning response by naloxone implicates an opioid peptide pathway; however, since naloxone is a non-selective opioid antagonist, it does not specify the type of opioid receptor involved. This study also examined the potential hypoxic tolerance modification by the opioid agonist, morphine, which was a useful tool for these experiments because it has central nervous system access and is relevant due to common clinical use. Morphine acts predominantly at the $\mu$ type opioid receptor, but also has affinities for the $\delta$ and $\kappa$ opioid receptors based on binding assays in guinea pig brain homogenate ${ }^{17}$. We hypothesized that morphine would augment HST. The results from the morphine experiments on $\mathrm{HC}$ mice showed no shift in the survival curves compared to saline-treated mice until a dose of $50 \mathrm{mg} / \mathrm{kg}$ was reached. This effect of morphine is likely to be due to toxic effects such as respiratory depression especially because this effect was seen only at a very high dose. It is unlikely that morphine depresses hypoxic tolerance by a mechanism identical to naloxone. Evidence supporting different mechanisms is that morphine does not alter the hypoxic conditioning mortality or the survival times of SC mice as was demonstrated with naloxone. This would suggest that morphine's action is a toxic side effect and not a direct effect on the ability of the mice to adapt. Our results do not allow us to make conclusions about specific receptor involvement. It is possible that more than one opioid receptor type is involved 
in this process and that different receptor types play different roles. More selective agonists and antagonists of the specific opioid receptors will be useful probes to identify the receptor type involved in hypoxic adaptation. Despite the lack of morphine's selectivity as a probe for the opioid receptor type involved, these experiments provide potentially relevant information concerning the clinical use of morphine in patients at risk of becoming hypoxic.

It is not surprising that endogenous opioid peptides are involved in the hypoxic conditioning response. Acute exposure to hypoxia induces a lower body temperature and initiates a spectrum of cardiovascular and respiratory responses including increased respıratory rate, heart rate and pulse pressure. Many of these responses are thought to be regulated by endogenous opioids ${ }^{5,9}$. Cardiovascular, pulmonary and thermoregulatory systems could be effector mechanisms to mediate hypoxic tolerance and thus regulate acute adaptation. One possible mechanism by which endogenous opioids could coordinate these various functions is through the nucleus of the solitary tract, a major autonomic relay nucleus and also known to be part of the endogenous opioid pathways ${ }^{1}$. The data presented confirm the lower body temperatures that occur with hypoxic conditioning ${ }^{21}$. Naloxone attenuated this change in body temperature indicating that these lower body temperatures may be induced by the action of endogenous opioid peptides. Thermoregulation

\section{REFERENCES}

1 Akıl, H , Watson, S J , Young, E , Lewls, M E , Khachaturian, H. and Walker, J.M , Endogenous opıo1ds. biology and function, Annu Rev Neurosct, 7 (1984) 223-255

2 Benedettı, J, Yuen, $\mathrm{K}$ and Young, L., Life tables and survivor function, BMDP P1L In W.J Dixon, M.B Brown, L Engelman and R I Jennrich (Eds.), BMDP Statistical Software Manual, Vol 2, University of Cahfornıa Press, Berkeley, CA, 1990, pp. 739-768.

3 Breslow, N, Covariance analysis of censored survival data, Btometrics, 30 (1974) 89-99

4 Chopp, M , Chen, H , Ho, K.-L., Dereski, M O, Brown, E , Hetzel, F W and Welch, K.M.A . Transient hyperthermia protects against subsequent forebrain ischemic cell damage in the rat, Neurology, 39 (1989) 1396-1398.

5 Clark, W G. Influence of opioids on central thermoregulatory mechanisms, Pharmacol. Biochem Behav, 10 (1979) 609-613

6 Eiger, S M, Kirsch, J R. and D'Alecy, L G . Hypoxic tolerance enhanced by B-hydroxybutyrate-glucagon in the mouse, Stroke, 11 (1980) 513-517

7 Foldes, F F, Lunn, J N , Moore, J and Brown, I.M , N-Allylnoroxymorphone a new potent narcotic antagonist, $A m J$ Med Scl, 245 (1963) 23-30

8 Gordon, C.J , Relationship between autonomic and behavioral thermoregulation in the mouse, Physiol Behav. 34 (1985) 687690

9 Holaday, J.W , Cardiovascular effects of endogenous opıate systems. Annu. Rev Pharmacol Toxicol., 23 (1983) 541-594

$10 \mathrm{Kirino}, \mathrm{T}$, Tsujta, $\mathrm{Y}$ and Tamura, A., Induced tolerance to ıschemı in gerbil hıppocampal neurons. $J$ Cereb Blood Flow is potentially an effective modulator of hypoxic tolerance by virtue of its effect on metabolic rate and therefore on oxygen demand ${ }^{27}$. The interaction of the endogenous opioid system with potential hypoxic adaptation effector mechanisms such as the thermoregulatory, cardiovascular and respiratory systems lends support to the hypothesis that the central nervous system pathway mediating the adaptation to hypoxic tolerance is opioid dependent.

These data support the conclusion that endogenous opioid peptides are necessary for acute adaptation to hypoxia. Mice given naloxone farled to adapt to hypoxia and did not lower their body temperature during hypoxic conditioning. A mechanism can now be proposed in which hypoxia is a stimulus that via a naloxone-blockable pathway is able to cause an increase in hypoxic tolerance possibly mediated by the effects of lowered body temperature and/or altered metabolism.

Acknowledgements This work was supported in part by the Veteran's Administration and contributions from both Upjohn and Johnson \& Johnson K PM was supported in part by NIGMF Pharm Scl Tr. Prog Grant No 2T326 M07767. Data were previously published in abstract form for the American Physiological Society Meetıng September 28-October 3, 1991 We would like to thank Dr Huda Akıl and Dr Keith Trujıllo for input and advice about endogenous opiold peptides We also thank John Warner of the Statistical Research Laboratory and The University of Mich1gan School of Public Health for assistance with statistical analysis and Marie Samida for assistance in preparing the manuscript

Metab , 11 (1991) 299-307

11 Kirsch, J R and D'Alecy, L G, Effect of altered avallability of energy-yıeldıng substrates upon survival from hypoxia in mice, Stroke, 10 (1979) 288-291

12 Kirsch. J.R and D'Alecy, L G., Role of tissue lactate and substrate avalability in 1.3-butanediol-enhanced hypoxic survival in the mouse, Stroke. 14 (1983) 971-976

13 Kirsch, J R, D'Alecy, L G and Mongroo, P.B., Butanediol induced ketosis increases tolerance to hypoxia in the mouse, Stroke, 11 (1980) 506-513.

14 Kitagawa, K, Matsumoto, M. Tagaya, M , Kuwabara, K . Hata, R , Handa, N.. Fukunaga, R., Kımura, K. and Kamada, T.. Hyperthermia-induced neuronal protection against ischemic injury in gerbils. J Cereb Blood Flow Metab., 11 (1991) 449452

15 Levine, J E and Beckel, D., Reversal of incipient brain death from head injury apnea at the scene of accidents, $N$ Engl $J$ Med , 301 (1979) 104

16 Lundy, E F, Luyckx, B A , Zelenock, G B and D'Alecy, L G , Butanediol induced cerebral protection in the instrumented Levine rat, Stroke, 15 (1984) 547-552.

17 Magnan, J., Paterson, S J , Tavanı, A and Kosterlitz, H W, The binding spectrum of narcotic analgesic drugs with different agonist and antagonist properties, Naunyn-Schmiedeberg's Arch. Pharmacol, 319 (1982) 197-205

18 Martın, W.R, Eades, C G , Thompson, J A , Huppler, R.E and Gibert, P.E. The effects of morphine- and nalorphine-like drugs in the nondependent and morphine-dependent chronic spinal dog, J Pharmacol Exp Ther, 197 (1976) 517-532

19 Merz, H, Stockhaus, K . Wick, H, Diastereoisomeric N-tetrahydrofurfurylnoroxymorphines with opıold agonıst-antagonıst 
properties, J Med. Chem., 20 (1977) 844-846.

20 Moursi, M.M., Luyckx, B.A. and D'Alecy, L.G., The role of ethanol in diluents of drugs that protect mice from hypoxia, Stroke, 14 (1983) 791-796.

21 Rising, C.L. and D'Alecy, L.G., Hypoxia-induced increases in hypoxic tolerance augmented by b-hydroxybutyrate in mice, Stroke, 20 (1989) 1219-1225.

22 Rose, J, Valtonen, S and Jennett, B., Avoidable factors contributing to death after head injury, Br J Med , 2 (1977) 615618.

23 Steen, P A. and Michenfelder, J.D., Cerebral protection with barbiturates. relation to anesthetic effect, Stroke, 9 (1978) 140142
24 West, J.B., The 1988 Stevenson Memorial Lecture. Physiolog1cal responses to severe hypoxia in man, Can $J$ Physiol Pharmacol , 67 (1989) 173-178

25 Wilhjelm, B H and Arnfred, I., Protective action of some anesthetics against anoxia, Acta Pharmacol Toxicol., 22 (1965) 93-98

26 Winston, J.M. and Roberts, R.J., Influence of carbon monoxIde, hypoxic hypoxia or potassium cyanide pretreatment on acute carbon monoxide and hypoxic hypoxia lethality, $J$ Pharmacol Exp Ther, 193 (1975) 713-719.

27 Wood, S C , Interactions between hypoxia and hypothermı, Annu Rev Physiol, 53 (1991) 71-85. 